\title{
The Comparison Between Non-High Risk Patients with and Without Cancer Diagnosed with Pulmonary Embolism
}

\author{
Kanseri Olan ve Olmayan Yüksek Riskli Olmayan Pulmoner Emboli \\ Hastalarının Karşılaştırılması
}

\author{
Tayfun CALISKAN $\odot$, Ozlem TURKOGLU $\odot$, Kadir CANOGLU $\bullet$, Omer AYTEN $\bullet$, Bengu SAYLAN $\odot$ \\ Oguzhan OKUTAN ${ }^{\oplus}$, Zafer KARTALOGLU ${ }^{\oplus}$
}

Ethics Committee Approval: This study approved by the Umraniye Training and Research Hospital Clinical Research Ethics Committee, 20 March 2019, 38.

Conflict of interest: The authors declare that they have no conflict of interest.

Funding: None.

Informed Consent: Not Applicable.
Cite as: Caliskan T, Turkoglu O, Canoglu K, et al. The comparison between non-high risk patients with and without cancer diagnosed with pulmonary embolism. Medeni Med J. $2021 ; 36: 30-5$.

\begin{abstract}
Objective: This study aimed to compare the pulmonary embolism (PE) location and clot burden on computed tomography pulmonary angiography (CTPA), the degree of right ventricular dysfunction (RVD), D-dimer, and cardiac troponin I (cTnI) levels, and the presence of a lower extremity deep venous thrombosis (DVT) in patients with and without cancer diagnosed with a non high risk pulmonary embolism (PE).

Method: We calculated Miller score for each patient for clot burden. The location of PE was also evaluated at CTPA. D-dimer and cardiac cTnl levels were measured. Patients had echocardiography for RVD and lower extremity color flow Doppler ultrasonography for DVT.

Results: The study included 71 patients with PE. The patients were divided into two groups according to the presence of cancer. There was no statistically significant difference for $D$-dimer levels $(P=0.15)$, $P E$ location $(P=0.67)$, clot burden $(P=0.34), R V D(P=0.28)$ and $D V T(P=0.33)$ between groups $(P=0.15)$. Cancer patients diagnosed as $P E$ had statistically significantly higher levels of cTnI than those who were diagnosed as $P E$ without cancer $(P=0.03)$.

Conclusion: There was no significant difference between patients diagnosed as PE with and without cancer in terms of D-dimer levels, clot burden and emboli location, RVD and DVT. cTnl levels were higher in non-high risk PE patients with cancer than these patients without cancer.
\end{abstract}

Keywords: Pulmonary embolism, cancer, thrombus, troponin, D-dimer

Öz

Amaç: Bu çalışma, kanseri olan ve olmayan yüksek riskli olmayan pulmoner emboli (PE) hastalarında pulmoner bilgisayarlı tomografik anjiyografide (PBTA) PE lokalizasyonu, trombüs yükü, sağ ventrikül disfonksiyonu (SVD), serum D-dimer, serum kardiyak troponin I (kTnl) ve alt ekstremite derin ven trombozu (DVT) varlığının karșllaștırılmasını amaçlamıștır.

Yöntem: Her hasta için trombüs yükü Miller Skoru ile hesaplandı. PE yeri PTBA'da değerlendirildi. Serum D-dimer, kTnI düzeyleri ölçüldü. Hastalara SVD için ekokardiyografi ve DVT için alt ekstremite renkli mod doppler ultrasonografi yapıldı.

Bulgular: PE tanılı yetmis bir hasta çalıșmaya alındı. Hastalar kanser varlığına göre iki gruba ayrıldı. Íki grup arasında $D$-dimer düzeyleri $(p=0,15)$, PE yeri $(p=0,67)$, trombüs yükü $(p=0,34), S V D$ $(p=0,28)$ ve $D V T(p=0,33)$ yönünden istatistiki anlamlı bir fark saptanmadı. Kanseri olan ve $P E$ tanısı konulan hastalar, kanser tanısı olmayanlara göre istatistiksel olarak anlamlı derecede daha yüksek $k T n I$ düzeylerine sahipti $(p=0,03)$.

Sonuç: Kanseri olan ve olmayan PE tanısı konulan hastalar arasında D-dimer, trombüs yükü, emboli yerleșimi, SVD ve DVT varlığı açısından fark saptanmadı. Kanseri olan yüksek riskli olmayan PE hastalarında kTnI düzeyleri, kanseri olmayan yüksek riskli olmayan PE hastalarından daha yüksekti.

Anahtar kelimeler: Pulmoner emboli, kanser, trombüs, troponin, D-dimer
Received: 7 January 2020

Accepted: 27 February 2021

Online First: 26 March 2021

Corresponding Author: T. Caliskan

ORCID: 0000-0002-7905-2430

Health Sciences University,

Sultan 2. Abdulhamit Han

Training and Research Hospital, Department of Pulmonology, Istanbul, Turkey

drtcaliskan@yahoo.com

\section{K. Canoglu}

ORCID: 0000-0003-1579-3392

Omer Ayten

ORCID: 0000-0002-2275-4378

B. Saylan

ORCID: 0000-0002-5922-0847

O. Okutan

ORCID: 0000-0002-4660-1595

Z. Kartaloglu

ORCID: 0000-0002-2954-6168

Health Sciences University,

Sultan 2. Abdulhamit Han

Training and Research Hospital,

Department of Pulmonology,

Istanbul, Turkey

O. Turkoglu

ORCID: 0000-0001-7712-2899

Health Sciences University,

Sultan 2. Abdulhamit Han

Training and Research Hospital,

Department of Radiology, Istanbul, Turkey 


\section{INTRODUCTION}

Cancer is a well-recognized risk factor for venous thromboembolic disease and the risk of pulmonary embolism (PE) and the overall risks of venous thromboembolism (VTE) in cancer patients is four times higher than the risk in the general population $^{1,2}$. In addition to its prevalence, PE increases morbidity and mortality in cancer patients ${ }^{2}$. In comparison with the general population, in cancer patients with a diagnosis of PE the incidence of major adverse events is 3-fold higher including major bleeding on anticoagulation, cardiovascular collapse and shock, recurrence of PE within 30 days $^{3-5}$. Accordingly, an alternative management strategy may be indicated for these patients.

The prognosis of patients with a PE is related with their ability to compensate for and to overcome the impairment in gas exchange, right ventricular strain, and reduced left ventricular filling pressures resulting from embolism. While baseline hemodynamic status and underlying disease are important prognostic indicators ${ }^{6}$, additional objective findings may be used for identifying patients at high risk for a poor outcome. Localization of emboli and the extent of clot burden (the obstructive index) can be assessed with computed tomography pulmonary angiography (CTPA) and it may be used for stratification of patients with $\mathrm{PE}^{7}$. The amount of thrombus burden determines the extent of hemodynamic collapse and damage to gas exchange ${ }^{6}$. However, in one study no correlation was observed between obstruction index and prognosis ${ }^{7}$. Echocardiography findings, troponin elevation, and brain natriuretic peptide (BNP) levels are also routinely used to define risk stratification of patients with $\mathrm{PE}^{1}$. $\mathrm{PE}$ in patients with shock or persistent arterial hypotension was defined as high-risk PE and others were defined as non-high-risk PE in the absence of these.

This study aimed to compare the PE location and clot burden on CTPA, the degree of right ven- tricular dysfunction (RVD), D-dimer, and cardiac troponin I (cTnI) levels, and the presence of a lower extremity deep venous thrombosis (DVT) in patients with or without cancer diagnosed with a non high-risk PE.

\section{MATERIAL and METHODS}

\section{Study design:}

This study was conducted in the Pulmonology Department of Sultan 2. Abdulhamit Han Training and Research Hospital. Imaging and clinical data were retrospectively reviewed. The study was approved by the Ethics Review Board. Patients included in the study were older than 18 years of age and underwent at least one CTPA to confirm the diagnosis of PE. In order to confirm the diagnosis of PE, CTPA was evaluated and reported by an experienced radiologist interested in chest radiology. A Miller Score was calculated for each patient, according to the degree of contrast filling defect found on CTPA ${ }^{8}$. The localization of the embolism was also evaluated at CTPA and recorded as right,and left-sided or bilateral PE. Cancer was diagnosed pathologically and all types of cancer patients were included in the study. Patients with cancer in remission were excluded. D-dimer and CTnI measurements were performed in the emergency department. Acute coronary syndrome and other cardiac diseases were ruled out by electrocardiography and echocardiography performed by a cardiology consultant. After hospitalization, lower extremity color Doppler ultrasonography was performed. Cases with PE were classified as low-risk, intermediate risk and high-risk patients based on early mortality risk according to the guidelines ${ }^{1}$. High-risk patients were hemodynamically unstable ones with shock or hypotension. Low-risk patients had no signs of RVD and elevated cardiac biomarkers. Intermediate-risk patients had either one (or none) positive or both positive but pulmonary embolism severity index (PESI) class III-IV or simple PESI $\geq 1$ score. Patients with high-risk PE, who were treated in intensive care unit and 
received thrombolytic therapy, were not included in the study. The patients with and without cancer diagnosed with a non-high risk PE were compared in terms of the PE location and clot burden on CTPA, D-dimer and, cTnI levels, the presence of right RVD, and DVT.

\section{Statistical Analysis:}

In the analysis, PSPP (free software under the terms of the GNU General Public License) was used. Descriptive analyzes (frequency distributions, percentages, mean, median, and standard deviation) and Kolmogorov-Smirnov normality distributions were used for the analysis of data. Mann-Whitney $U$ test was used to measure the difference between groups since the data was not normally distributed. Chi-square test was used for the differences between discrete variables. The results were evaluated at $95 \%$ confidence interval and with $\mathrm{p}<0.05$ significance level.

\section{RESULTS}

The study included 71 patients. All patients were diagnosed as having a PE by CTPA. There were 20 patients in the malignancy group and 51 patients constituted the group without malignancy. The mean age of the group without malignancy (male $49 \%$, and female $51 \%$ ) was $62.86+20.80$ years. The mean age of the group with malignancy (male 55\%, and female $45 \%$ ) was $70.90+15.92$ years (Table 1 ). There was no statistically significant difference for age and gender between groups ( $p$ values are $=0.18$ and 0.65 , respectively).

The mean D-dimer levels of patients with and without cancer were $2134.82 \pm 1527.96 \mathrm{ng} / \mathrm{mL}$, and $1504.95 \pm 1265.98 \mathrm{ng} / \mathrm{mL}$, respectively. (Table 2 ). There was no statistically significant difference for $\mathrm{D}$-dimer levels between the two groups $(\mathrm{P}=0.15)$.

Of the patients without cancer, $41.2 \%$ had emboli on the right, $17.6 \%$ on the left and $41.2 \%$ on both sides. In patients with cancer, emboli were on the right side in $40.0 \%$, on the left side in $10.0 \%$ and on both sides in $50.0 \%$. There was no statistically significant difference as for the localization of emboli between the two groups $(P=0.67)$. The mean Miller scores were $6.55 \pm 3.33$, and $5.94 \pm 3.58$ in patients with, and without cancer, respectively. There was no statistically sig-

Table 1. Demographics of the study groups.

\begin{tabular}{llclc}
\hline & $\begin{array}{l}\text { No Cancer } \\
(\mathbf{n = 5 1 )}\end{array}$ & $\begin{array}{l}\text { Cancer } \\
(\mathbf{n = 2 0 )}\end{array}$ & $\begin{array}{l}\text { Total } \\
(\mathbf{n = 7 1 )}\end{array}$ & P-value \\
\hline Male (n, \%) & $25(49.0)$ & $11(55.0)$ & $36(50.7)$ & 0.65 \\
Female (n, \%) & $26(51.0)$ & $9(45.0)$ & $35(49.3)$ & \\
Age (Mean \pm SD) & $62.86 \pm 20.80$ & $70.90 \pm 15.92$ & $65.13 \pm 19.78$ & 0.18 \\
\hline n: number, SD: standard deviation. & &
\end{tabular}

Table 2. Comparison of the parameters between groups.

\begin{tabular}{|c|c|c|c|c|}
\hline & No Cancer & Cancer & Total & P-value \\
\hline \multicolumn{5}{|l|}{ Emboli Localization (n, \%) } \\
\hline Right & $21(41.2)$ & $8(40.0)$ & $29(40.8)$ & \\
\hline Left & $9(17.6)$ & $2(10.0)$ & $11(15.5)$ & 0.67 \\
\hline Bilateral & $21(41.2)$ & $10(50.0)$ & $31(43.7)$ & \\
\hline \multicolumn{5}{|l|}{ DVT (n, \%) } \\
\hline No & $32(62.7)$ & $10(50.0)$ & 42 (59.2) & 0.33 \\
\hline Yes & $19(37.3)$ & $10(50.0)$ & $29(40.8)$ & \\
\hline \multicolumn{5}{|l|}{ RVD (n, \%) } \\
\hline No & $35(68.6)$ & $11(55.0)$ & $46(64.8)$ & 0.28 \\
\hline Yes & $16(31.4)$ & $9(45.0)$ & $25(35.2)$ & \\
\hline Miller score $($ Mean \pm SD $)$ & $5.94 \pm 3.58$ & $6.55 \pm 3.33$ & $6.11 \pm 3.50$ & 0.34 \\
\hline D-Dimer (ng/mL) & $1504.95 \pm 1265.98$ & $2134.82 \pm 1527.96$ & $1682.38 \pm 1363.78$ & 0.15 \\
\hline cTnI (ng/L) & $4 \pm 7$ & $23 \pm 54$ & $10 \pm 30$ & 0.03 \\
\hline
\end{tabular}

n: number, SD: standard deviation, DVT: deep venous thrombosis, RVD: right ventricular dysfunction, cTnI: cardiac troponin I. 
nificant difference for clot burden between the two groups ( $\mathrm{P}=0.34)$. RVD was found in $45 \%$, and $31.4 \%$ of patients with, and without cancer, respectively. There was no statistically significant difference as for the presence of RVD between groups $(\mathrm{P}=0.28)$. The mean cTnI levels of patients with and without cancer were $23 \pm 54 \mathrm{ng} / \mathrm{L}$, and $4 \pm 7 \mathrm{ng} / \mathrm{L}$, respectively. Patients with a PE in the setting of malignancy had significantly higher levels of cTnI than those without diagnosis of cancer $(\mathrm{P}=0.03)$. DVT was detected in $50 \%$, and $37.3 \%$ of the patients with, and without cancer. There was no statistically significant intergroup difference as for the presence of DVT ( $\mathrm{P}=0.33)$.

\section{DISCUSSION}

There was no difference between patients diagnosed as PE with and without cancer in terms of D-dimer levels, clot burden and emboli location, RVD and DVT, but the cTnI level was significantly higher in the patients with PE in the setting of an underlying diagnosis of cancer in this study.

Troponin elevation at the time of diagnosis of acute PE is an important prognostic laboratory parameter. Patients with PE and elevated troponin level are at high risk of short-term mortality and other adverse outcomes ${ }^{9}$. Increased serum cTnI levels may suggest the diagnosis of severe $P E$ in clinic and echocardiographic suspicion of $P E^{10}$. Increased troponin levels were found as an independent prognostic marker among PE patients with increased brain natriuretic peptide (BNP) levels ${ }^{11}$. In another study, although higher cTnI levels predicted fatal PE, cTnI was not an independent predictor of 30-day all-cause mortality in hemodynamically stable patients with $\mathrm{PE}^{12}$. In addition to mortality risk stratification, cTnI levels were also found as predictive of RVD in patients presenting with PE, though the ability of CTnI to predict RVD was higher in patients without cancer than in those with cancer history ${ }^{13}$. In our study, the cTnI level was significantly higher in patients with PE in the setting of underlying diagnosis of cancer.

PE is an important clinical problem and patients with PE have a high mortality rate ${ }^{14}$. Cancer frequently causes thrombosis because of its prothrombotic effect. Patients with cancer have a four to six times higher risk for VTE compared to those without. Khorana et al. showed that the mortality risk of VTE patients with cancer was higher than patients without ${ }^{15}$. Hospitalization due to VTE, use of prolonged anticoagulants, treatment-related complications, VTE recurrence and delay in cancer treatment increased morbidity in cancer patients ${ }^{16}$.

Recurrence of thromboembolism and treatmentrelated complications are more common in patients with venous thrombosis diagnosed with cancer than in patients without ${ }^{17}$. Because of these issues, different approaches to the treatment of PE are recommended in cancer patients ${ }^{17}$. Measurement of D-dimer levels is usually used to exclude PE. Although measurement of D-dimer using ELISA (Enzyme-linked immunoassay) method is apparently reliable to rule out PE in cancer patients but using a high cut-off value of D-dimer in cancer patients may increase its clinical usefulness ${ }^{18}$. Patients with cancer have higher levels of D-dimer in general, and Ay et al. found that there was an association between high D-dimer levels and poor survival and increased mortality risk in cancer patients ${ }^{19}$. In our study, D-dimer levels did not differ between patients with and without cancer who were diagnosed with a PE.

In this study, we showed that, there was no difference for clot burden between patients diagnosed as PE with and without cancer. Consensus has not been reached as to whether the embolic burden as assessed on a CTPA has a role in the risk stratification of patients diagnosed with PE. Clot burden may be included in the risk stratifying tools such as PESI for patients with $\mathrm{PE}^{6}$. While larger clot volume induces RVD more often, it has not been associated with short-term mortality ${ }^{20}$. 
Moreover, no correlation was found between the obstruction index on CTPA and prognosis ${ }^{7}$. At the time of writing clot burden as assessed by CTPA was not included in the risk classification algorithms ${ }^{1}$.

In our study, there was no difference in RVD between patients with a PE regardless of their cancer status. Evaluating patients with acute PE for the presence of RVD using Doppler imaging echocardiography and/or laboratory markers may provide clinical utility as a strategy for risk stratification $^{21}$. There is no definitive decision on the role of RVD in predicting prognosis in hemodynamically stable patients with $\mathrm{PE}^{22}$, and there is mounting evidence of its usefulness for risk stratification. RVD detected on admission is associated with increased risk of mortality in low-risk patients with $\mathrm{PE}^{22,23}$. While echocardiographic examination is not recommended as of the diagnostic work up in hemodynamically stable patients with a suspected, but not proven PE; echocardiography plays a role in the prognostic stratification of patients diagnosed with an intermediate or lowrisk $\mathrm{PE}^{24}$.

Cancer patients have an increased risk of developing all forms for VTE, both DVTs and PEs, compared with patients without cancer ${ }^{25}$. DVT can be detected with advanced diagnostic methods in about $70 \%$ of the patients with $\mathrm{PE}^{11}$. With that in mind, when dealing with PE possibility, it is suggested that compression ultrasound is safe and proven particularly efficient as a frontline test, especially in elderly patients; however, Girard et al. ${ }^{26}$ did not support routine screening for DVT in patients who already have a CTPA-proven PE. The overall incidences of PE and DVT in patients hospitalized with cancer were twice the rates of non-cancer patients ${ }^{27}$. In our study, we found that a DVT was coexistent with a PE more frequently in patients with cancer than those without, but the difference was not statistically significant.

\section{Limitations:}

There are some limitations in this study. The study was performed retrospectively using the electronic data system of our hospital. Patients with high-risk PE who were treated in intensive care or received thrombolytic therapy were excluded. Another limitation of the study was the small number of patients included in our study. Cancer patients were not classified according to the histopathological cell types.

\section{CONCLUSION}

There was no difference between patients with and without cancer diagnosed with a non-highrisk PE in terms of D-dimer, RVD, DVT, clot burden and localization of emboli. The cTnI levels were higher in non-high-risk PE patients with cancer than those without cancer. Given the prognostic implications of an elevated cTnI levels in the setting of PE, patients with cancer and a PE may have a more severe prognosis. Comparison of patients with and without cancer with PE will be important in determining the clinical approach to these patients in the future.

\section{REFERENCES}

1. Konstantinides SV, Torbicki A, Agnelli G, et al. 2014 ESC guidelines on the diagnosis and management of acute pulmonary embolism. Eur Heart J. 2014;35:3033-69. [CrossRef]

2. Heit JA, Silverstein MD, Mohr DN, Petterson TM, O'Fallon WM, Melton LJ. Risk factors for deep vein thrombosis and pulmonary embolism: a population-based casecontrol study. Arch Intern Med. 2000;160:809-15. [CrossRef]

3. Sanchez O, Trinquart L, Caille V, et al. Prognostic factors for pulmonary embolism: the prep study, a prospective multicenter cohort study. Am J Respir Crit Care Med. 2010;181:168-73. [CrossRef]

4. Trujillo-Santos J, Nieto JA, Tiberio G, et al. Predicting recurrences or major bleeding in cancer patients with venous thromboembolism. Thromb Haemost. 2008; 100:435-9. [CrossRef]

5. Levitan N, Dowlati A, Remick SC, et al. Rates of initial and recurrent thromboembolic disease among patients with malignancy versus those without malignancy. Risk analysis using Medicare claims data. Medicine (Baltimore). 1999;78:285-91. [CrossRef]

6. Patel A, Kassar K, Veer M, Doyle M, Kanwar M. Clot burden serves as an effective predictor of 30 day mortality 
in patients with acute pulmonary embolism. JACC. 2018;71:A1933. [CrossRef]

7. Vedovati MC, Germini F, Agnelli G, Becattini C. Prognostic role of embolic burden assessed at computed tomography angiography in patients with acute pulmonary embolism: systematic review and meta-analysis. JThromb Haemost. 2013;11:2092-102. [CrossRef]

8. Bankier AA, Janata K, Fleischmann D, et al. Severity assessment of acute pulmonary embolism with spiral CT: evaluation of two modified angiographic scores and comparison with clinical data. J Thorac Imaging. 1997;12:150-8. [CrossRef]

9. Becattini C, Vedovati MC, Agnelli G. Prognostic value of troponins in acute pulmonary embolism: a meta-analysis. Circulation. 2007;1 16:427-33. [CrossRef]

10. Kilinc G, Dogan OT, Berk S, Epozturk K, Ozsahin SL, Akkurt I. Significance of serum cardiac troponin I levels in pulmonary embolism. J Thorac Dis. 2012;4:588-93. [CrossRef]

11. Lega JC, Lacasse Y, Lakhal L, Provencher S. Natriuretic peptides and troponins in pulmonary embolism: a metaanalysis. Thorax. 2009;64:869-75. [CrossRef]

12. Jiménez D, Díaz G, Molina J, et al. Troponin I and risk stratification of patients with acute nonmassive pulmonary embolism. Eur Respir J. 2008;31:847-53. [CrossRef]

13. Keller K, Geyer M, Beule J, Coldewey M, Balzer JO, Dippold W. Impact of cancer on the effectiveness of cardiac Troponin I to predict right ventricular dysfunction in acute pulmonary embolism. Thorac Cancer. 2015;6:584-8. [CrossRef]

14. Goldhaber SZ, Visani L, De Rosa M. Acute pulmonary embolism: clinical outcomes in the International Cooperative Pulmonary Embolism Registry (ICOPER). Lancet. 1999;353:1386-9. [CrossRef]

15. Khorana AA, Francis CW, Culakova E, Kuderer NM, Lyman GH. Thromboembolism is a leading cause of death in cancer patients receiving outpatient chemotherapy. J Thromb Haemost. 2007;5:632-4. [CrossRef]

16. Lyman GH. Venous thromboembolism in the patient with cancer: focus on burden of disease and benefits of thromboprophylaxis. Cancer. 2011;117:1334-49. [CrossRef]

17. Prandoni P, Lensing AWA, Piccioli A, et al. Recurrent venous thromboembolism and bleeding complications during anticoagulant treatment in patients with cancer and venous thrombosis. Blood. 2002;100:3484-8.
[CrossRef]

18. Righini M, Le Gal G, De Lucia S, et al. Clinical usefulness of D-dimer testing in cancer patients with suspected pulmonary embolism. Thromb Haemost. 2006;95:715-9. [CrossRef]

19. Ay C, Dunkler D, Pirker R, et al. High D-dimer levels are associated with poor prognosis in cancer patients. Haematologica. 2012;97:1158-64. [CrossRef]

20. Furlan A, Aghayev A, Chang CCH, et al. Short-term mortality in acute pulmonary embolism: clot burden and signs of right heart dysfunction at CT pulmonary angiography. Radiology. 2012;265:283-93. [CrossRef]

21. Ribeiro A, Lindmarker P, Juhlin-Dannfelt A, Johnsson $H$, Jorfeldt L. Echocardiography Doppler in pulmonary embolism: right ventricular dysfunction as a predictor of mortality rate. Am Heart J. 1997;134:479-87. [CrossRef]

22. ten Wolde M, Söhne M, Quak E, Mac Gillavry MR, Büller HR. Prognostic value of echocardiographically assessed right ventricular dysfunction in patients with pulmonary embolism. Arch Intern Med. 2004;164:1685-9. [CrossRef]

23. Kucher N, Rossi E, De Rosa M, Goldhaber SZ. Prognostic role of echocardiography among patients with acute pulmonary embolism and a systolic arterial pressure of $90 \mathrm{~mm} \mathrm{Hg}$ or higher. Arch Intern Med. 2005;165:177781. [CrossRef]

24. Torbicki A, Perrier A, Konstantinides S, et al. Guidelines on the diagnosis and management of acute pulmonary embolism: the Task Force for the Diagnosis and Management of Acute Pulmonary Embolism of the European Society of Cardiology (ESC). Eur Heart J. 2008;29:2276-315. [CrossRef]

25. Blom JW, Vanderschoot JPM, Oostindiër MJ, Osanto S, van der Meer FJM, Rosendaal FR. Incidence of venous thrombosis in a large cohort of 66,329 cancer patients: results of a record linkage study. J Thromb Haemost. 2006;4:529-35. [CrossRef]

26. Girard P, Sanchez O, Leroyer C, et al. Deep venous thrombosis in patients with acute pulmonary embolism: prevalence, risk factors, and clinical significance. Chest. 2005; 128: 1593-600. [CrossRef]

27. Stein PD, Beemath A, Meyers FA, Skaf E, Sanchez J, Olson RE. Incidence of venous thromboembolism in patients hospitalized with cancer. Am J Med. 2006; 119:60-8. [CrossRef] 